\title{
Effect of Non Performing Assets on Profitability: A Study of Select Nationalized, Private and Foreign Banks Operating in India
}

\author{
Neha Varma \\ University School of Management Studies, Guru Gobind Singh Indraprastha University, New Delhi, India
}

Correspondence Author: Neha Varma, University School of Management Studies, Guru Gobind Singh Indraprastha University, New Delhi, India

Received date: 11March 2019, Accepted date: 22 April 2019, Online date: 30 April 2019

Copyright: (C) 2019 Neha Varma, et al. This is an open-access article distributed under the terms of the Creative Commons Attribution License, which permits unrestricted use, distribution, and reproduction in any medium, provided the original author and source are credited.

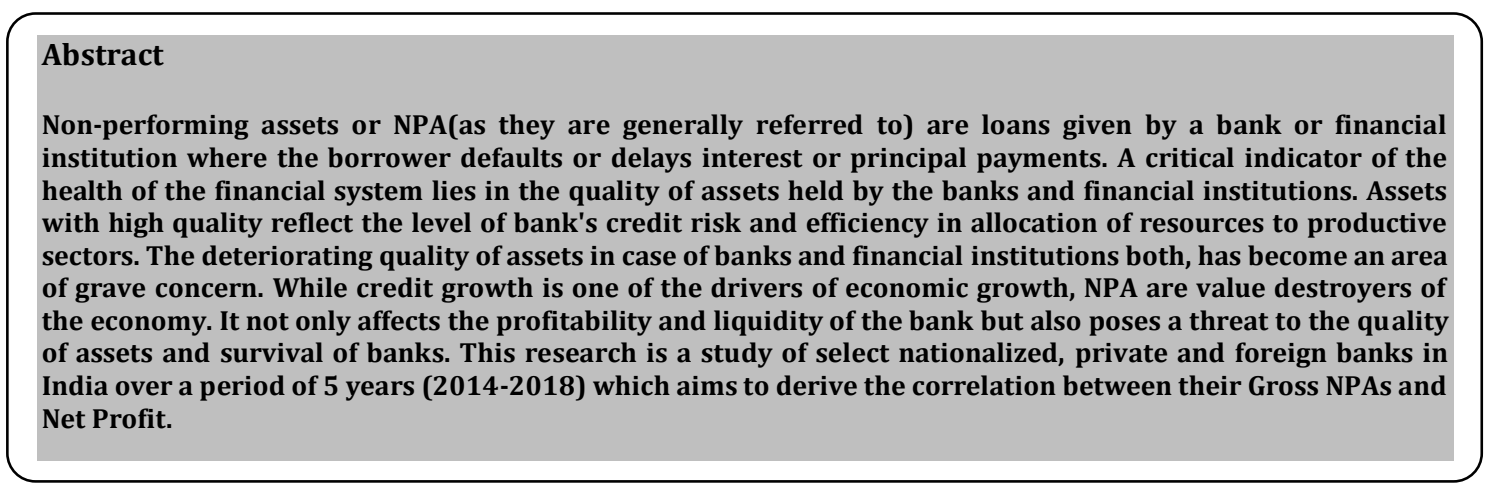

Keywords: NPA, Net Profit, Gross NPA

\section{INTRODUCTION}

The banking sector plays a vital role in the economy of any country. It facilitates the flow of funds and ensures the efficient allocation of financial resources thereby stabilizing the financial system. The health of an economy is thus, directly related to the financial status of its banks. During the subprime crisis of 2008 , the effect of which was felt globally, India was among the least affected countries due to the strict rules and regulations of the banking sector that prevailed. India is a developing and growing economy and has a respectable position in terms of financial stability at the global level. Nevertheless, banks in India are experiencing the perils of Non-Performing Assets (NPA).NPAs can be defined as a non-performing loan or a loan for which interest and principal are not being repaid and interest is hence, getting overdue for months in a row. Such loans, in turn, affect the capability and solvency of the banks.

As per RBI's asset classification norms brought in with effect from March 31, 2004, a non-performing asset shall be a loan or an advance where interest and / or instalment of principal remain overdue for a period of more than 90 days in respect of a Term Loan.

According to the asset classification given by RBI, banks should classify their non-performing assets in the following three categories:

- Sub-standard Assets

- Doubtful Assets

- Loss assets

Substandard asset: (i) with effect from March 31, 2005, an asset would be classified as sub-standard if it remained NPA for a period less than or equal to 12 months. (ii) An asset where the terms of the loan agreement regarding interest and principal have been re-negotiated or rescheduled after commencement of production should be classified as sub-standard and should remain in such category for at least 12 months of satisfactory performance under the re-negotiated or rescheduled terms.

Doubtful assets: An asset is required to be classified as doubtful, if it has remained NPA for more than 12 months (w.e.f March 31, 2005)

Loss Assets: An asset is said to be a loss asset where loss has been identified by the bank or internal or external auditors or by the Co-operation Department or by the Reserve Bank of India inspection but the amount has not been written off, wholly or partly.

\section{Review of Literature}

According to a study conducted by [1] (2018) on the trend and recovery of non-performing assets of Indian Banks, NPA has a severe impact on the liquidity, profitability and credit of the banking sector and if not managed effectively it can become a major problem for any economy.

An empirical study of impact of NPA over the profitability of private sector banks in India, conducted by [2] (2017) concluded that it is not possible to make the NPA ratio zero, however, it is possible to reduce this ratio through proper management, precautions and timely follow-ups.

As per the study conducted by [3] (2016) about a comparison of NPA in the public sector banks and private sector banks in India, the NPA was higher in case of the public sector banks when compared to the private sector banks. The year 2016 was said to be the black mark for the public sector banks as the percentage of the NPA was more than double that recorded in the previous year.

A study conducted by [4] (2017) indicated that the performance of public sector banks in India have been poor in the past few years. This has majorly been due to the Non-Performing Assets related issues which have been suppressed to some extent. 
According to the research conducted by [5] (2016), the NPAs are increasing and while the large banks are able to maintain the losses by NPAs, the small banks are not able to recover. Hence, the banking sector should aim at effective management of NPAs.

A study on the Effect of the Non-Performing Assets on the Profitability of Public Sector Banks of India conducted by [6] (2016) shows that NPA has a negative and significance, impact on bank's financial performance in the period under study and public sector banks should be permitted devise their own ways to address the problems of NPAs.

According to a study conducted by [7]. (2012), showing the inverse relationship between profitability and NPAs. The study exhibited the fact, only by an effective declining trend of NPA the bank can have an increasing trend of profitability. Non-performing assets symbolize non-performing loans, which leads to misallocation of credit investments from projects that actually need it. This spills over the banking system and contract money stock, which then leads to economic contraction and affects its profitability and liquidity.

\subsection{Objective of the Study}

\section{RESEARCH METHODOLOGY}

To find a correlation between profitability and non-performing assets for private, public and foreign banks operating in India

\subsection{Sample}

The Sample for the study was taken from the individual bank's annual reports. Balance sheets and Profit and loss account of each individual bank is studied from period 2014 to 2018 and data regarding Net Profit and Gross NPAs is extracted. In all data of 46 banks was taken out of which 21 were Nationalized Banks, 17 were Private Banks and 7 were Foreign Banks operating in India. These banks are taken on the basis of availability of data for the last five years.

\section{RESULTS AND DISCUSSIONS}

The correlation was applied to the data collected for select private banks, nationalized banks as well as foreign banks operating in India to know the relation between the Gross NPA and Net profit.

From Table No 1 it can be inferred that banks such as Axis Bank Ltd., Dhanlaxmi Bank Ltd., Jammu \& Kashmir Bank Ltd., Lakshmi Vilas Bank Ltd., Tamilnad Mercantile Bank Ltd. and YES Bank Ltd. have a significant negative correlation between Gross Non-performing assets and net profits. On the other hand, a positive correlation can be seen in select other banks in the same category namely, City Union Bank Ltd., DCB Bank Ltd., HDFC Bank, IndusInd Bank Ltd, Kotak Mahindra Bank Ltd. and RBL Bank Ltd. However, no correlation can be seen between the Gross NPA and the Net Profit for Catholic Syrian Bank Ltd., Federal Bank Ltd., ICICI Bank Ltd., Karnataka Bank Ltd., Karur Vysya Bank Ltd. and South Indian Bank Ltd.

In case of Nationalized banks, (as seen in Table No 2), largely, a negative correlation is visible between the Gross NPA and Net profits. The banks showing such correlation are Allahabad Bank, Andhra Bank, Bank of Baroda, Bank of India, Bank of Maharashtra, Canara Bank, Central Bank of India, Corporation Bank, Dena Bank, IDBI Bank Limited, Indian Overseas Bank, Oriental Bank of Commerce, Punjab \& Sind Bank, Punjab National Bank, State Bank of India, Syndicate Bank, UCO Bank and Union Bank of India. This could be due to many reasons such as relaxed lending norms, lapses due to diligence and selling of unsecured loans in large amounts in order to face competition. On the other hand, no correlation could be seen in Indian Bank and United Bank of India. However, Vijaya Bank shows a positive correlation between Gross NPA and Net Profits.

In case of Foreign banks (Table 3) having a presence in India, Citibank shows a significant negative correlation between Gross Non-performing assets and net profits. While HSBC Ltd., Standard Chartered Bank and American Express Banking Corp show a positive correlation, other banks such as Australia and New Zealand Banking Group Ltd., DBS Bank Ltd. and Bank of America exhibit no correlation.

Further the Gross NPA values were regressed on Net Profit values of these banks using the partial least square model using Smart PLS 3 software. The advantage of using PLS is that it works well with a small sample and does not have the problem of data normality. Table 4 and Table 5 shows the results of Cannonical correlations, variance explained, and reliability of regression model and validity of regression model. The Cronbach Alpha reliability should be above 0.65 [8] and Composite reliability value should be above 0.70 [9]. Table 4 shows that both Cronbach alpha reliability values and Composite reliability value are well above required value for all the three regression models derived for Nationalized Banks, Private Banks and Foreign Banks. The validity of the regression models was assessed through convergent validity which is nothing but variance extracted. According to Fornell and Larcker [9], convergent validity is achieved, if the variance-extracted value is greater than 0.50 . Results depict that the variance extracted all the variables ranged from 0.647 to 0.999 (Table 5). This indicates that the regression models for all three types of banks are significant.

Canonical correlation analyzes the relationship between sets of variables, with one set of variables typically seen as the independent set and another as the dependent set. Here the independent set is taken as Gross NPA values for last 5 years and net profit values of last 5 years are taken as dependent set. The canonical correlation score for nationalized banks is .925 , for private banks, it is .700 and for foreign banks it is .979 . All three correlation score are positive and significantly high. This means that there is a significant positive correlation between the Gross NPA and Net Profits of nationalized, private and foreign banks.

Also, the variance explained in net profit of nationalized banks by gross NPA is $85.6 \%$. This means that non-performing assets are having a huge effect on the profitability of nationalized banks. The variance explained by gross NPA in net profit of private banks is $49 \%$. This indicates that almost $50 \%$ of the profitability of private banks is determined by non-performing assets. In case of foreign banks, this variance explained is $95.8 \%$. This means almost entire profitability of these banks is determined by NPA's.

Table 1: List of Private Banks taken for study along with the correlations of Gross NPA and Net Profit

\begin{tabular}{|c|c|}
\hline Banks & Correlation between Gross NPA and Net Profit \\
\hline Axis Bank Ltd. & $-0.954^{* *}$ \\
\hline Catholic Syrian Bank Ltd. & -0.128 \\
\hline City Union Bank Ltd. & $0.990^{* *}$ \\
\hline DCB Bank Ltd. & $0.955^{* *}$ \\
\hline Dhanlaxmi Bank Ltd. & $-0.754^{* *}$ \\
\hline Federal Bank Ltd. & -0.102 \\
\hline HDFC Bank Ltd & $0.977^{* *}$ \\
\hline ICICI Bank Ltd. & 0.388 \\
\hline IndusInd Bank Ltd & $0.944^{* *}$ \\
\hline Jamm \& Kashmir Bank Ltd. & $-0.755^{* *}$ \\
\hline Karnataka Bank Ltd. & -0.237 \\
\hline Karur Vysya Bank Ltd. & -0.455 \\
\hline Kotak Mahindra Bank Ltd & $0.906^{* *}$ \\
\hline Lakshmi Vilas Bank Ltd. & $-0.967^{* *}$ \\
\hline RBL Bank Ltd. & $0.988^{* *}$ \\
\hline South Indian Bank Ltd. & -0.372 \\
\hline Tamilnad Mercantile Bank Ltd. & $-0.796^{* *}$ \\
\hline YES Bank Ltd. & $-0.713^{* *}$ \\
\hline Note: * indicate correlation significant at .05 level and ** indicate correlation significant at .01 level \\
\hline
\end{tabular}


Citation: Neha Varma, 2019. Effect of Non Performing Assets on Profitability: A Study of Select Nationalized, Private and Foreign Banks Operating in India. Journal of Applied Sciences Research., 15(2): 14-17. DOI: 10.22587/jasr.2019.15.2.4

Table 2: List of Nationalized Banks taken for study along with the correlations of Gross NPA and Net Profit

\begin{tabular}{|c|c|}
\hline Banks & Correlation between Gross NPA and Net Profit \\
\hline Allahabad Bank & $-0.887^{*}$ \\
\hline Andhra Bank & $-0.896^{* *}$ \\
\hline Bank of Baroda & $-0.759^{* *}$ \\
\hline Bank of India & $-0.905^{* *}$ \\
\hline Bank of Maharashtra & $-0.942^{* *}$ \\
\hline Canara Bank & $-0.854^{* *}$ \\
\hline Central Bank of India & $-0.910^{* *}$ \\
\hline Corporation Bank & $-0.757^{*}$ \\
\hline Dena Bank & $-0.960^{* *}$ \\
\hline IDBI Bank Limited & $-0.966^{* *}$ \\
\hline Indian Bank & 0.276 \\
\hline Indian Overseas Bank & $-0.948^{* *}$ \\
\hline Oriental Bank of Commerce & $-0.845^{* *}$ \\
\hline Punjab \& Sind Bank & $-0.758^{* *}$ \\
\hline Punjab National Bank & $-0.802^{* *}$ \\
\hline State Bank of India & $-0.979^{*}$ \\
\hline Syndicate Bank & $-0.878^{*}$ \\
\hline UCO Bank & $-0.977^{*}$ \\
\hline Union Bank of India & $-0.888^{* *}$ \\
\hline United Bank of India & -0.486 \\
\hline Vijaya Bank & $0.686^{*}$ \\
\hline Note: * indicate correlation significant at .05 level and ** indicate correlation significant at .01 level \\
\hline
\end{tabular}

Table 3: List of Foreign Banks taken for study along with the correlations of Gross NPA and Net Profit

Table 3: List of Foreign Banks taken for study along with the correlations of Gross NPA and Net Profit
\begin{tabular}{|c|c|}
\hline Banks & Correlation between Gross NPA and Net Profit \\
\hline Australia and New Zealand Banking Group Ltd. & 0.038 \\
\hline HSBC Ltd & $0.918^{* *}$ \\
\hline DBS Bank Ltd. & 0.478 \\
\hline Standard Chartered Bank & $0.859^{* *}$ \\
\hline American Express Banking Corp. & $0.886^{* *}$ \\
\hline Bank of America & 0.118 \\
\hline Citibank N.A. & $-0.864^{* *}$ \\
\hline Note: * indicate correlation significant at .05 level and ** indicate correlation significant at .01 level
\end{tabular}

Table 4: Regression Analysis of Non-Performing Assets on Gross Profits for Select Nationalized, Private and Foreign Banks using Smart PLS 3.

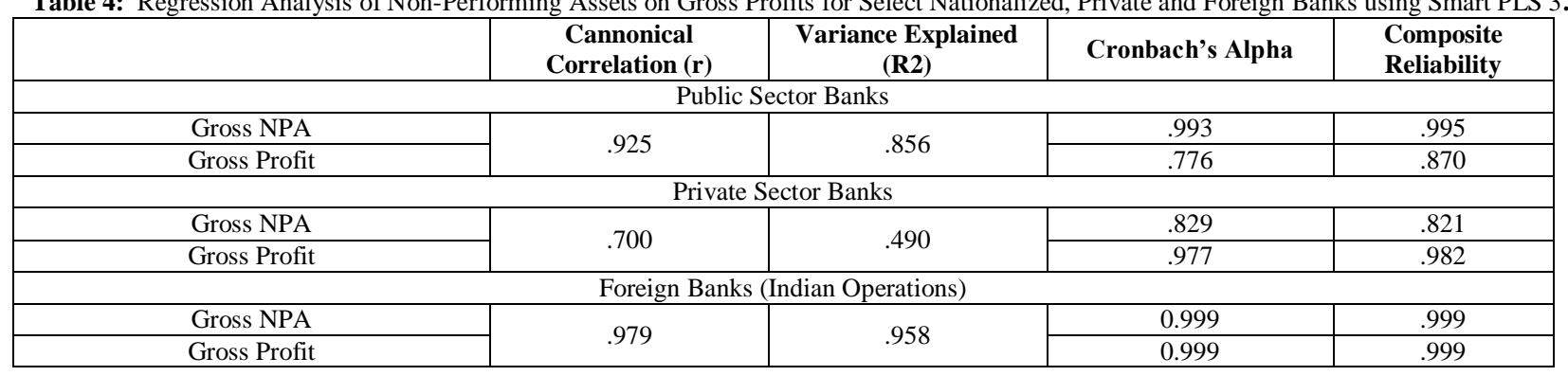

Table 5: Variance Extracted for each Variable of Gross NPA and Gross Profit for Nationalized, Private and Foreign Banks

\begin{tabular}{|c|c|c|c|c|c|c|}
\hline & Public Sector Banks & \multicolumn{2}{|c|}{ Private Sector Banks } & \multicolumn{2}{c|}{ Foreign Banks } \\
\hline & GNPA & NP & GNPA & NP & GNPA & .998 \\
\hline Year 2014 & .975 & .957 & .791 & .979 & .999 & .999 \\
\hline Year 2015 & .998 & .975 & .790 & .986 & .999 & .999 \\
\hline Year 2016 & .982 & .817 & .922 & .991 & .995 & .999 \\
\hline Year 2017 & .986 & .871 & .993 & .965 & .99 \\
\hline Year 2018 & .995 & .917 & .647 & .853 & .998 & .99 \\
\hline
\end{tabular}

\section{CONCLUSION}

As per the study conducted, it can be concluded that there is a significant impact of the Non-Performing Assets on the profitability of the private, nationalized and foreign banks in India. NPA affects the efficiency of the banks and thus the profitability. Recycling of bank credit is affected by NPAs as lendable resources shrink and adversely impact profitability. High NPAs also shadow the image of the banks in both domestic and international markets. This leads to business contraction and low profitability. Banks lend at higher interest rates to low rated borrowers as a result of their efforts to increase income from lending, thus,NPAs leads to adverse selection. High nonperforming assets, low profitability, riskier business and high NPAs work in a vicious circle against the bank and may jeopardize the very survival of the banks.

\section{REFERENCES}

[1] Dr. Sangeeta Kumar, A Study on Non Performing Assets of Indians Banks: Trend and Recovery, International Journal of Electronics, Electrical and Computational System, 2018; 7( 3):457-462

[2] Abhani Dhara K, Empirical study of impact of NPA over the profitability of leading private sector banks, International Journal of Applied Research,2017;3(8):16-20

[3] Ayub Ahamed KS, Vishwanath Panwar, A Comparative Study of Non-Performing Assets (NPA) in Private Sector Banks and Public Sector Banks in India, International Journal of Commerce, Business and Management,2016;5(6):26-33 
Citation: Neha Varma, 2019. Effect of Non Performing Assets on Profitability: A Study of Select Nationalized, Private and Foreign Banks Operating in India. Journal of Applied Sciences Research., 15(2): 14-17. DOI: 10.22587/jasr.2019.15.2.4

[4] Sri Ayan Chakraborty, Effect of NPA on Banks Profitability, International Journal of Engineering Technology, Management and Applied Sciences, 2017;5(5):201-210

[5] K. Prasanth Kiran \& T. Mary Jones, Effect Of Non Performing Assets On The Profitability Of Banks - A Selective Study, International Journal of Business and General Management,2016;5(2):53-60

[6] Omid Sharifi, Javaid Akhter, Effect of Non Performing Assets on the Profitability of Public Sector Banks of India, International Journal of Engineering and Management Research,2016;6(5):383-388

[7] Namita Rajput, Monika Gupta, Mr. Ajay Kumar Chauhan, Profitability and Credit Culture of NPAS:An Empirical Analysis of PSBs, International Journal of Marketing, Financial Services \& Management Research,2012;1(9): 91-109

[8] Nunnally, J.C.,Psychometric Theory, (1st Ed.). New York: McGraw-Hill, 1967

[9] Fornell, C., and Larcker, D. F. (), Evaluating structural equation models with unobservable variables and measurement error. Journal of Marketing Research, 1981:39-50. 